\title{
Features of the Processes of Lipoperoxidation and Antioxidant Protection in the Pathogenesis of Infertility in Men of Different Ethnic Groups, Carriers of Nonfunctional Polymorphisms of the GSTT1 and GSTM1 Genes
}

\author{
N. A. Kurashova, $\mathrm{PhD}, \mathrm{ScD}^{1^{*}}$; T. A. Bairova, $\mathrm{PhD}, \mathrm{ScD}^{1}$; M. I. Dolgikh, $\mathrm{PhD}^{1}$; \\ B. G. Dashiev²; L. I. Kolesnikova, PhD, ScD ${ }^{1}$ \\ 'Scientific Centre for Family Health and Human Reproduction Problems, Irkutsk, the Russian Federation \\ ${ }^{2}$ Republican Perinatal Center, Ulan-Ude, the Russian Federation
}

\begin{abstract}
A comparative analysis was carried out of the parameters of lipoperoxidation and antioxidant protection in fertile and infertile men of two ethnic groups (Caucasians and Mongoloids), who were carriers of different genotypes of xenobiotic biotransformation genes (GSTT1 and GSTM1). In serum and ejaculate, we determined the content of TBA-active products, $\alpha$-tocopherol, reduced glutathione (GSH) and oxidized glutathione (GSSG); the activity of glutathione-S-transferase (GST), glutathione peroxidase (GPO) and glutathione reductase (GR); and total antioxidant activity (AOA). It was found that in Caucasian fertile men, carriers of genotypes $\operatorname{GSTT1}(* 0 / * 0) / G S T M 1(* 0 / * 0)$, there was a decrease in GST activity in serum and ejaculate with an increase in AOA in these substrates in comparison with similar indicators in carriers of genotypes $G S T T 1(1+/ 1+) / G S T M 1(1+/ 1+)$. In Mongoloid fertile men, carriers of genotypes $\operatorname{GSTT1}\left({ }^{*} 0 /{ }^{*} 0\right) / G S T M 1\left(* 0 / *^{*} 0\right)$, in comparison with similar indices in carriers of genotypes GSTT1 $(1+/ 1+) / G S T M 1(1+/ 1+)$, we found an increase in serum content of $\alpha$-tocopherol and activity of GPO, a decrease in GST activity, and a decrease in the level of $\alpha$-tocopherol in the ejaculate. In Caucasians with infertility, carriers of genotypes $\operatorname{GSTT1}\left(* 0 / *^{*} 0\right) / G S T M 1(0 * / * 0)$, we found decreased activity of GST in the blood and ejaculate. In this group, we also registered a decrease in the GSH level, with an increase in the level TBA-active products and GPO activity. In infertile Mongoloids, carriers of genotypes $\operatorname{GSTT1}\left(*^{*} 0 / *^{*}\right) / \operatorname{GSTM} 1\left({ }^{*} 0 / * 0\right)$, we found an increase in the level TBA-active products and GPO activity and a decrease in serum $\alpha$-tocopherol level.(International Journal of Biomedicine. 2019;9(1):31-34.)
\end{abstract}

Key Words: oxidative stress $\bullet$ male infertility $\bullet$ ethnicity $\bullet$ GSTT1 $\bullet$ GSTM1

\section{Introduction}

Modern negative trends, which characterize the reproductive health of the population, cause great concern..$^{(1-3)}$ Russia has one of the highest rates of marital infertility, reaching $19 \%-20 \% .{ }^{(4,5)}$ The proportion of the "male" factor in the structure of family infertility has reached $50 \%{ }^{(2,6,7)}$ As a rule, male infertility is the result of various pathological processes in the body that have an adverse effect on the endocrine

*Corresponding author: Nadezhda A. Kurashova, PhD, ScD. Scientific Centre for Family Health and Human Reproduction Problems, Irkutsk, the Russian Federation. E-mail: nakurashova@, yandex.ru system, including sex glands. Professor Eduardo Ruiz-Castañé (Director of the Andrology Department of the Fundació Puigvert Clinic, Barcelona) noted, in order to identify the possible causes of reproductive disorders, factors associated with "subfertility, potential correction of anomalies, changes in genetic aspects" should be considered. ${ }^{\left({ }^{8}\right)}$ Male fertility is affected by various metabolic, toxic, immune and vascular disorders, congenital and acquired diseases, inflammatory processes, and even mental disorders. . $^{(1-3,9,10)}$

Genetic factors play a special role in the pathogenesis of male infertility..$^{(3,11)}$ Different types of chromosomal and gene disorders affect the male reproductive system at different levels: from the normal formation of the male genital organs and spermatogenesis to ejaculation and fertilization of the 
egg. ${ }^{(3,11,12)}$ The gene system plays a key role in the processes of ensuring and maintaining the normal vital activity of cells, including spermatozoa. This is primarily because the genes that are part of this system encode enzymes that catalyze various types of chemical transformations in the cell. ${ }^{(12)}$ The GST gene family plays a primary role, taking part in the second phase of detoxification of xenobiotics and in protecting cells against oxidative stress. ${ }^{(11,13-15)}$

The purpose of this study was to investigate the parameters of the lipid peroxidation and antioxidant protection system associated with polymorphisms of biotransformation genes in fertile and infertile men of different ethnic groups.

\section{Materials and Methods}

A retrospective analysis of the results of a survey of Mongolian men (using the example of the Buryats; $n=143$; mean age of $31.6 \pm 5.9$ years) and Caucasians (using the Russian example; $\mathrm{n}=222$; mean age of $29.9 \pm 5.3$ years) of infertile couples who applied to the Republican Perinatal Center, the city of Ulan-Ude. Two control groups of 53 Buriats and 104 Russians (mean age of $31.9 \pm 7.5$ and $30.2 \pm 3.6$ years, respectively) were formed, consisting of healthy men with realized reproductive function. All men had a laboratory and clinical examination by an andrologist, including an ultrasonic scan of scrotum and prostate. Macroscopic and microscopic examination of ejaculate was performed in accordance with with the WHO recommendations (2010). The study was conducted in accordance with ethical principles of the Declaration of Helsinki (2000; revised October 2013, Fortaleza, Brazil). Written informed consent was obtained from all participants.

In serum and ejaculate of the examined men, the content of thiobarbituric acid (TBA)-active products (TBA-AP) was determined by the method of V.B. Gavrilova et al.(1984), $\alpha$-tocopherol - by the method of R.Ch.Chernyauskene et al. (1984), total antioxidant activity (AOA) according to GI Klebanov et al. (1988). The content of reduced glutathione (GSH) and oxidized glutathione (GSSG) was determined by the method of P.Y. Hissin (1976). The activity of glutathioneS-transferase (GST), glutathione peroxidase (GPO) and glutathione reductase (GR) was estimated by the method of A.I.Karpishchenko (2002). The measurements were performed using a Shimadzu RF-1501 spectrofluorophotometer.

DNA samples were genotyped for polymorphisms in the genes GSTT1 and GSTM1. DNA was isolated from venous blood samples using the sorbent method with the certified reagent kit DNA-Sorb-B (Central Research Institute of Epidemiology, Moscow, Russia). Genetic polymorphism of insertion/deletion in the GSTT1 and GSTM1 genes was determined by PCR in the automatic thermocycler Tercyc using the reagent kit of Central Research Institute of Epidemiology (Moscow, Russia).

Amplification products were detected in a 3\% agarose gel; the electrophoresis results were registered and documented with the help of the system of computer gel documentation GelDoc. GSTM1+, GSTT1+ (wild type) and GSTM1*0 and GSTT1 *0 homozygotes (null genotype) were analyzed.
Patients with genetic causes of infertility (AZF deletions, CFTR mutations, mutational changes in the number of CAG repeats controlled by androgen receptors) were excluded from the study.

The statistical analysis was performed using the software package Statistica 6.1 (StatSoft, USA) and Biostat. Deviation from Hardy-Weinberg equilibrium and differences in allele distributions between the two groups were assessed by $\chi 2$ - test and Fisher's exact test. Two-tailed $P$ values $<0.05$ were considered statistically significant.

\section{Results and Discussion}

In fertile Caucasian men who carried nonfunctional genotypes GSTT1 $(* 0 / * 0) / G S T M 1(* 0 / * 0)$, a statistically significant decrease in GST activity by $50 \%$ in blood plasma and $35 \%$ in ejaculate was found, with an increase in total serum AOA by $22 \%$ and ejaculate by $32 \%$ when compared with similar indicators in carriers of functional genotypes $\operatorname{GSTT1}(1+/ 1+) / \operatorname{GSTM1}(1+/ 1+)($ Table 1).

Table 1.

Components of the lipid peroxidation and antioxidant protection system in fertile Caucasian men, carriers of different polymorphisms of xenobiotic biotransformation genes

\begin{tabular}{|l|c|c|}
\hline \multicolumn{1}{|c|}{ Variable } & $\begin{array}{c}\text { GSTT1 }(* 0 / * 0) / \\
\text { GSTM1 }(* 0 / * 0)\end{array}$ & $\begin{array}{c}\text { GSTT1 }(1+/ 1+) / \\
\text { GSTM1 }(1+/ 1+)\end{array}$ \\
\hline Total AOA (serum) & $18.62 \pm 4.75$ & $14.52 \pm 4.72 *$ \\
\hline GST (serum) & $560.45 \pm 357.67$ & $1122.19 \pm 607.66^{*}$ \\
\hline Total AOA (ejaculate) & $4.5 \pm 3.59$ & $3.08 \pm 2.52 *$ \\
\hline GST (ejaculate) & $378.32 \pm 304.13$ & $585.53 \pm 554.93 *$ \\
\hline
\end{tabular}

* $-P<0.05$ between two groups.

The increased level of total AOA, which characterizes the total activity of enzymatic and non-enzymatic inhibitors of free radical oxidation in fertile Caucasians, is a reliable protection of cell membranes, including spermatozoa.

In fertile Mongoloid men who carried genotypes GSTT1 $(* 0 / * 0) / G S T M 1(* 0 / * 0)$, we found a statistically significant decrease in blood GST activity by $45 \%$ and an increase in blood GPO activity by $21 \%$ (Table 2 ).

Table 2.

Components of the lipid peroxidation and antioxidant protection system in fertile Mongoloid men, carriers of different polymorphisms of xenobiotic biotransformation genes

\begin{tabular}{|l|c|c|}
\hline \multicolumn{1}{|c|}{ Variable } & $\begin{array}{l}\text { GSTT1 }(* 0 / * 0) / \\
\text { GSTM1 }(* 0 * / 0)\end{array}$ & $\begin{array}{c}\text { GSTT1 }(1+/ 1+) / \\
\text { GSTM1 }(1+/ 1+)\end{array}$ \\
\hline $\begin{array}{l}\alpha \text { - tocopherol } \\
\text { (serum) }\end{array}$ & $9.36 \pm 3.20$ & $7.77 \pm 2.32^{*}$ \\
\hline GPO (serum) & $566.7 \pm 167.2$ & $467.5 \pm 223.1 *$ \\
\hline GST (serum) & $642.6 \pm 566.8$ & $1170.0 \pm 944.4 *$ \\
\hline $\begin{array}{l}\alpha \text { - tocopherol } \\
\text { (ejaculate) }\end{array}$ & $2.68 \pm 1.19$ & $4.76 \pm 3.05^{*}$ \\
\hline
\end{tabular}

$*$ - $P<0.05$ between two groups. 
In infertile Caucasians, carriers of genotypes GSTT1 $(* 0 / * 0) / G S T M 1(* 0 / * 0)$, the activity of GST was reduced by $23 \%$ in the blood and $32 \%$ in the ejaculate. They also registered a decrease in the GSH content by $6 \%$ and an increase in the TBA-AP content by $32 \%$ and blood GPO activity by $17 \%$ (Table 3).

Table 3.

Components of the lipid peroxidation and antioxidant protection system in infertile Caucasian men, carriers of different polymorphisms of xenobiotic biotransformation genes

\begin{tabular}{|l|c|c|}
\hline \multicolumn{1}{|c|}{ Variable } & $\begin{array}{c}\text { GSTT1 }(* 0 / * 0) / \\
\text { GSTM1 }(* 0 / * 0)\end{array}$ & $\begin{array}{c}\text { GSTT1 }(1+/ 1+) / \\
\text { GSTM1 }(1+/ 1+)\end{array}$ \\
\hline TBA-AP (serum) & $1.21 \pm 0.66$ & $0.82 \pm 0.54 *$ \\
\hline GSH (serum) & $1.71 \pm 0.22$ & $1.82 \pm 0.23 *$ \\
\hline GPO (serum) & $175.89 \pm 113.62$ & $145.29 \pm 59.76^{*}$ \\
\hline GST (serum) & $794.73 \pm 667.08$ & $1033.39 \pm 773.46^{*}$ \\
\hline GST (ejaculate) & $550.26 \pm 510.36$ & $806.55 \pm 686.26^{*}$ \\
\hline
\end{tabular}

* - $P<0.05$ between two groups.

In infertile Mongoloids, carriers of genotypes GSTT1 $(* 0 / * 0) / G S T M 1(* 0 / * 0)$, we found an increase in blood content of TBA-AP by $18 \%$ and blood GPO activity by $25 \%$, with a decrease in serum $\alpha$-tocopherol level by $13 \%$. The ejaculate showed a decrease in $\alpha$-tocopherol level by $12 \%$, GSSG level by $43 \%$ and GST activity by $46 \%$ (Table 4 ).

\section{Table 4.}

Components of the lipid peroxidation and antioxidant protection system in infertile Mongoloid men, carriers of different polymorphisms of xenobiotic biotransformation genes

\begin{tabular}{|l|c|c|}
\hline \multicolumn{1}{|c|}{ Variable } & $\begin{array}{c}\text { GSTT1 }(* 0 / * 0) / \\
\text { GSTM1 }(* 0 / * 0)\end{array}$ & $\begin{array}{c}\text { GSTT1 }(1+/ 1+) / \\
\text { GSTM1 }(1+/ 1+)\end{array}$ \\
\hline TBA-AP (serum) & $1.16 \pm 0.48$ & $0.94 \pm 0.53^{*}$ \\
\hline $\begin{array}{l}\alpha \text { - tocopherol } \\
\text { (serum) }\end{array}$ & $8.52 \pm 2.75$ & $9.74 \pm 3.19^{*}$ \\
\hline GPO (serum) & $213.7 \pm 141.5$ & $159.8 \pm 71.7 *$ \\
\hline $\begin{array}{l}\alpha-\text { tocopherol } \\
\text { (ejaculate) }\end{array}$ & $2.91 \pm 1.06$ & $3.33 \pm 1.32^{*}$ \\
\hline GSSG (ejaculate) & $1.8 \pm 1.17$ & $3.16 \pm 2.05^{*}$ \\
\hline GST (ejaculate) & $615.8 \pm 525.2$ & $1141.9 \pm 789.5^{*}$ \\
\hline
\end{tabular}

* $-P<0.05$ between two groups.

The study found that men with infertility, both Caucasians and Mongoloids, produce potentially damaging factors (TBA-AP), which exceed the capacity of the body's natural antioxidant defense, leading to cell damage and, consequently, oxidative stress. A genetically determined imbalance in the system of glutathione-dependent antioxidant protection determines the activation of lipid peroxidation and contributes to a significant weakening of the metabolic and detoxifying functions of the body in infertile men, both Caucasians and Mongoloids. As a result, the susceptibility of cells to the damaging effects of xenobiotics, which adversely affect any changes in the external and internal constants of the germ cell formation process, increases significantly.

Thus, genetic factors determine the change in the oxidative-antioxidant balance, both at the system and at the local level, leading to dysfunctions of the male reproductive system and, as a consequence, to a decrease in fertility. Identification of carriage of the polymorphic variants of the genes GSTT1 and GSTM1, as well as determination of the enzymes of the thiol-disulfide system, can be recommended for additional estimation of the risk of developing reproductive disorders in men.

\section{Conflict of Interest} interests.

The authors declare that they have no competing

\section{References}

1. Bisht S, Faiq M, Tolahunase M, Dada R. Oxidative stress and male infertility. Nat Rev Urol. 2017;14(8):470-485. doi: 10.1038/nrurol.2017.69.

2. Kurashova NA, Dolgikh MI, Ershova OA, Gavrilova OA, Osipova EV, Dashiev BG, et al. Associations of polymorphic variants of the biotransformation genes with the components of the glutathione system in men with infertility. International Journal of Biomedicine 2017;3(7):226-230. doi: 10.21103/ Article7(3)_OA13

3. O'Flynn O'Brien KL, Varghese AC, Agarwal A. The genetic causes of male factor infertility: a review. Fertil Steril 2010;93(1):1-12. doi:10.1016/j.fertnstert.2009.10.045

4. Kolesnikova LI, Kolesnikov SI, Kurashova NA, Osadchuk LV, Osadchuk AV, Dolgikh MI, et al. Reproductive health and peculiarities of lipid peroxidation-antioxidant defense system in men of the main ethnic groups of the Baikal region. Bull Exp Biol Med. 2015;160(1):32-4. doi: 10.1007/s10517-0153091-6.

5. Kolesnikova LI, Kurashova NA, Bairova TA, Dolgikh MI, Ershova OA, Natyaganova LV, et sl. Features of lipoperoxidation, antioxidant defense, and thiol/disulfide system in the pathogenesis of infertility in males, carriers of nonfunctional variants of GSTT1 and GSTM1 gene polymorphisms. Bull Exp Biol Med. 2017;163(3): 378-380. doi: 10.1007/s10517-017-3808-9.

6. Agarwal A, Mulgund A, Sharma R, Sabanegh E. Mechanisms of oligozoospermia: an oxidative stress perspective. Syst Biol Reprod Med. 2014;60(4):206-16. doi: 10.3109/19396368.2014.918675.

7. Agarwal A, Cho CL, Esteves SC, Majzoub A. Development of treatment strategies in men with vulnerable sperm. Transl Androl Urol. 2017;6(Suppl 4):S476-S478. doi: 10.21037/tau.2017.04.28

8. Discussion satellite symposium. Oxidative stress as a cause of male infertility. The management of the infertile couple. Effektivnaja farmakoterapija. 2014;(32):58-62. [In Russian].

9. Aitken RJ, Smith TB, Jobling MS, Baker MA \& De Iuliis GN. Oxidative stress and male reproductive health. Asian J Androl. 2014;16(1):31-8. doi:10.4103/1008-682X.122203.

10. Darenskaya MA, Kolesnikov SI, Rychkova LV, Grebenkina 
LA, Kolesnikova LI. Oxidative stress and antioxidant defense parameters in different diseases: ethnic aspects. Free Radical Biology \& Medicine. 2018;1(120):60. doi: 10.1016/j.freeradbiomed.2018.04.199

11. Safarinejad MR, Dadkhah F, Ali Asgari M, Hosseini SY, Kolahi AA, Iran-Pour E. Glutathione S-transferase polymorphisms (GSTM1, GSTT1, GSTP1) and male factor infertility risk: a pooled analysis of studies. Urol J. 2012;9(3):541-8.

12. Belyaeva EV, Yershova OA, Astahova TA, Bugun OV. [Glutathione S-transferase polymorphism in ethnic groups living in Eastern Siberia]. Vavilov Journal of Genetics and Breeding. 2017; 21(5):576-580. doi: 10.18699/VJ17.274. [Article in Russian].
13. Agarwal A, Virk G, Ong C, du Plessis SS. Effect of oxidative stress on male reproduction. World J Mens Health. 2014;32:1-17. doi: 10.5534/wjmh.2014.32.1.1.

14. Kolesnikova LI, Kolesnikov SI, Darenskaya MA, Grebenkina LA, Kolesnikova LR., Korytov LI, Suslikova MI. Oxidative stress as a mechanism of reduced glucose absorption under conditions of immobilization stress. Bull Exp Biol Med. 2017;164(2):132-135. doi: 10.1007/s10517017-3941-5.

15. Trofimova T, Lizneva D, Suturina L, Walker W, Chen Yh, Azziz R, Layman LC. Genetic basis of eugonadal and hypogonadal female reproductive disorders. Best Pract Res Clin Obstet Gynaecol. 2017;44:3-14. doi: 10.1016/j. bpobgyn.2017.05.003. 